\title{
Lipid Oxidation and Fatty Acid Profile Related to Broiler Breast Meat Color Abnormalities
}

\author{
Adriana Lourenço Soares ${ }^{1}$, Denis Fabrício Marchi ${ }^{1}$, Makoto Matsushita ${ }^{2}$, Paulo Donizeti \\ Guarnieri $^{3}$, Adriana Aparecida Droval ${ }^{1}$, Elza Iouko Ida ${ }^{1}$ and Massami Shimokomaki ${ }^{1,3^{*}}$ \\ ${ }^{I}$ Departamento de Tecnologia de Alimentos e Medicamentos; Centro de Ciências Agrárias; Universidade Estadual \\ de Londrina; C. P.: 6001; 86051-970; Londrina - PR - Brasil. ${ }^{2}$ Universidade Estadual de Maringá; Maringá - PR - \\ Brasil. ${ }^{3}$ Faculdade de Ciências Farmacêuticas; Universidade de São Paulo; São Paulo - SP - Brasil
}

\begin{abstract}
The aim of this work was to study the influence of lipid oxidation on broiler breast meat (Pectoralis major $m$ ) color abnormalities. There were $27.0 \%$ more lipid oxidation in PSE in relation to normal meat and $41.0 \%$ more in relation to $D F D$-like meat $(p \leq 0.05)$. The fatty acid profile was also significantly different since the arachidonic acid (AA) fraction increased 38.6 and $70.5 \%$ in PSE meat comparing to normal and DFD-like meats, respectively. The ratio PUFA/SFA changed in these three types of meat: 0.736, 0.713 and 0.694 for PSE, normal and DFD-like meat respectively, reflecting the highest production of polyunsaturated fatty acids in the PSE meat samples. Results indicated that phospholipase A2 enzyme activities played a relevant role towards the development of PSE-meat syndrome in a cascade of biochemical reactions promoting the formation of free radicals from AA, which ultimately damaged the muscle membrane systems.
\end{abstract}

Key words: PSE meat, DFD meat, arachidonic acid

\section{INTRODUCTION}

The considerable variation in breast fillet color is a continuing problem for the broiler meat industries. For example, in a recent survey carried out at a Brazilian commercial plant a 20.0-25.0\% of the flock presented broiler breast PSE (Pale, Soft, Exudative) meat and 0.30-6.0\% as DFD-like meat (Dark, Firm and Dry) (Soares et al, 2003a). These results are the consequence of several factors including pre-slaughtering management (Guarnieri at al. 2004), animal nutrition (Olivo et al, 2001) and possibly poultry genetics related to the calcium channels through ryanodine receptor proteins (Strasburg and Chiang, 2003, Lara et al, 2003). Although much is known about pig PSE and despite intensive scientific efforts, the fundamental biochemical cause of this syndrome in avian still awaits further confirmation.

Resulting in their reduced acceptability, lipid oxidation is the main cause of the deterioration of meat and meat products. Rancidity starts soon after the death of the animal and affects meat color, taste, texture and nutritive value (Morrissey et al, 1998, Soares et al, 2004). The main substrates involved oxidative decomposition of unsaturated fatty acids, components of phospholipids and triglycerides of cell membranes.

*Author for correspondence: mshimo@uel.br 
Through the catalytic action of metal ions, in the presence of various factors such as light, increased temperature and oxygen, these fatty acids increase the unstable organic compounds in autoxidation reactions, involving the free radicals, which can initiate the meat lipid oxidation cycle (St Angelo, 1996). Soares et al. (2003b) postulated that thermal stress promoted higher mitochondrial phospholipase A2 (PLA2) activity in the presence of higher concentrations of $\mathrm{Ca}^{2+}$ and that this could be the triggering factor in initiating the characteristic symptoms, leading to broiler PSE meat formation. PLA2 is a lypolytic enzyme which acts upon phospholipid membrane, liberating arachidonic acid (Murakami and Kudo, 2002). Thus, the aim of this work was to determine quantitatively the lipid oxidation and fatty acid profiles of broiler breast samples either with PSE or DFD-like meat color characteristics.

\section{MATERIALS AND METHODS}

\section{Materials}

In these experiments, chickens $(n=45)$ of Cobb lineage and 42 days old were used. All the birds were sacrificed according to the commercial routine plant procedures, i.e. electrical stunning, bleeding, defeathering, evisceration, carcass water cooling, deboning and refrigeration (Northcutt, 2001, Guarnieri et al., 2004). The time from the bleeding step to obtain the final breast muscle samples was $90 \mathrm{~min}$. The $\mathrm{pH}$ and the color values of samples were determined after $24 \mathrm{~h}$ storage at $4^{\circ} \mathrm{C}$. Lipid oxidation and fatty acid profile analyses were carried out in samples after 30 days of storage at $-18^{\circ} \mathrm{C}$.

\section{pH Measurement}

$\mathrm{pH}$ was measured by inserting the electrodes into the breast muscle using a $\mathrm{pH}$ meter system (Mettler - Toledo 345) in each sample group $(n=15)$. Analyses were performed in triplicate on refrigerated samples $24 \mathrm{~h}$ postmortem as reported in Olivo et al (2001).

\section{Color Measurement}

A Minolta CR10 colorimeter was used to evaluate the color, $\mathrm{L}^{*}$ (lightness), $\mathrm{a}^{*}$ and $\mathrm{b}^{*}$ (CIELAB color system) on the posterior surface of the intact skinless breast muscles at $24 \mathrm{~h}$ postmortem. The color values were measured at three different sites on the same sample from each group $(n=15)$. These sites were the proximal and distal extremity of the muscle and medial side at the halfway point between extremities (Olivo et al, 2001).

\section{Samples Classification}

Samples were classified as PSE, DFD-like and normal meat samples based on the previous established parameters associated to $\mathrm{pH}$ such as $\mathrm{L}^{*} \geq 53.0$ as PSE, $\mathrm{L}^{*} \leq 44.0$ as DFD-like and $44.0<$ $\mathrm{L}^{*}<53.0$ as normal group (Soares et al, 2002).

\section{Lipid Oxidation}

This was carried out in $20 \mathrm{~g}$ of homogenized sample (in duplicate) in ten samples from each group randomly taken following the technique of Tarladgis et al (1964). Results were expressed in $\mathrm{mg}$ of TBARS (Thiobarbituric Acid Reactive Substances)/kg of sample.

\section{Fatty acid profile}

Fatty acid profile was determined with five repetitions of each sample group through methyl ester preparation by transmethylation according to the procedure of ISO (1978), using $2 \mathrm{~mol} / \mathrm{L} \mathrm{KOH}$ in methanol and n-heptane. Fatty acid methyl esters (FAME) were analyzed using a Shimadzu 14A (Japan) gas chromatograph equipped with a flame ionization detector and a fused silica capillary column $(100 \mathrm{~m} \times 0.25 \mathrm{~mm})$ with $0.25 \mu \mathrm{m}$ of CP Sil-88. The column temperature was programmed at $10^{\circ} \mathrm{C} / \mathrm{min}$ from 80 to $240{ }^{\circ} \mathrm{C}$. The injection port and detector were maintained at 200 and $220^{\circ} \mathrm{C}$, respectively. The carrier gas was hydrogen $(1.2 \mathrm{~mL} / \mathrm{min})$ and the make-up gas was nitrogen $(30 \mathrm{~mL} / \mathrm{min})$; and split used was $1 / 100$. The identification of fatty acids was based on authentic standards (Sigma). The peak areas were determined by the CG-300 computing integrater (CG Instruments, Brazil). The final results were expressed as relative percentages of the fatty acids identified (Ruiz et al, 2005).

\section{Statistical Analysis}

Statistical analyses were performed using the Statistica software packet (Oklahoma, USA 1995). The Tukey test was applied to compare the mean values among three groups: PSE, DFD-like and normal breast meats. 


\section{RESULTS}

\section{PSE meat characterization}

In Table 1, the results of $\mathrm{pH}$ values and color measurements for characterization of PSE, normal and DFD-like broiler breast meats are presented. As expected, PSE meat samples had the lowest $\mathrm{pH}$ values; DFD-like samples had higher $\mathrm{pH}$ than normal meat samples $(p \leq 0.05)$. The Minolta $\mathrm{L}^{*}$ values, which expressed the meat brightness, were highest in the PSE group, indicating paler meat in comparison sequentially to that of normal meat and DFD-like samples, thus confirming previous results (Olivo, et al, 2001, Soares et al, 2003b,
Guarnieri et al, 2004, Fletcher, 1999, Alvarado and Sams, 2004). The $a^{*}$ and $b^{*}, a^{*}$ values were significantly lower for PSE meat samples in relation to normal and DFD-like meat while $b^{*}$ values did not show any significant difference $(\mathrm{p} \leq 0.05)$, similar to those reported by Fletcher (1999).

\section{Lipid Oxidation}

Lipid oxidation in PSE, normal and DFD-like broiler breast meat is shown in Table 2. PSE meat samples were $27.0 \%$ more lipid oxidized than normal samples and $41.0 \%$ more oxidized in relation to DFD-like meat $(\mathrm{p} \leq 0.05)$.

Table 1 - $\mathrm{pH}$ and color values for PSE, normal and DFD-like broiler breast meats.

\begin{tabular}{lcccc}
\hline Samples & PH & L $^{*}$ & $\mathbf{a}^{*}$ & $\mathbf{b}^{*}$ \\
\hline PSE & $5.9^{\mathrm{c}} \pm 0.1$ & $57^{\mathrm{a}} \pm 4$ & $1.9^{\mathrm{b}} \pm 1.1$ & $7.2^{\mathrm{a}} \pm 2.2$ \\
Normal & $6.0^{\mathrm{b}} \pm 0.1$ & $49^{\mathrm{b}} \pm 2$ & $3.8^{\mathrm{a}} \pm 1.5$ & $6.6^{\mathrm{a}} \pm 1.9$ \\
DFD-like & $6.1^{\mathrm{a}} \pm 0.1$ & $43^{\mathrm{c}} \pm 1$ & $4.2^{\mathrm{a}} \pm 0.7$ & $5.9^{\mathrm{a}} \pm 1.5$ \\
\hline
\end{tabular}

Means within columns with different superscript are significantly different $(\mathrm{p} \leq 0.05)$.

Table 2 - Lipid oxidation for PSE, normal and DFD-like broiler breast meats.

\begin{tabular}{cc}
\hline Samples & TBARS (mg/kg of samples) \\
\hline PSE & $0.44^{\mathrm{a}} \pm 0.11 *$ \\
Normal & $0.32^{\mathrm{b}} \pm 0.07 *$ \\
DFD-like & $0.26^{\mathrm{b}} \pm 0.04 *$ \\
\hline
\end{tabular}

$* \mathrm{p} \leq 0.05$.

\section{Fatty acid Profile}

At least two fatty acid concentrations were different in relation to PSE and other meat samples $(\mathrm{p} \leq 0.05)$. Myristic acid (14:0) and arachidonic acid (20:4 n6) were highest in PSE meat in relation to normal and DFD-like meat samples. However, myristic acid was only significantly different between PSE and DFD-like samples (Table 3).

Table 3 also showed that the total saturated fatty acid (SFA) and monounsaturated fatty acid (MUFA) were not significantly different among the three samples. However, the content of polyunsaturated fatty acid (PUFA) was higher in the PSE compared DFD- like meat samples $(\mathrm{p} \leq 0.05)$, although there was a tendency to be also higher comparing to normal samples.

\section{DISCUSSION}

A proposed scheme to explain the relationship between PSE meat and development of lipid oxidation is illustrated in Figure 1. Endogenous thermal stress promotes a higher intracellular phospholipase A2 (PLA2) activity in the presence of micromolar elevation in intracellular $\mathrm{Ca}^{2+}$ as originally proposed by Cheah et al (1986) in pigs and by Soares et al-(2003b) in broiler. As these authors originally hypothesized, this enzymatic reaction might be the triggering factor to initiate the formation of PSE meat by increasing substantially the peroxidation reactions, confirmed by the results shown in Table 2 . This higher lipid oxidation (Table 2) and the relative excessive production of arachidonic acid in PSE meat samples (Table 3) corroborated the previous assumption that PLA2 activity was directly related to PSE syndrome occurrence (Soares et al, 2003b). 
Table 3 - Fatty acid composition for PSE, normal and DFD-like broiler breast meat samples.

\begin{tabular}{llll}
\hline Fatty acid & \multicolumn{1}{c}{ PSE } & \multicolumn{1}{c}{ Non PSE } & \multicolumn{1}{c}{ DFD-like } \\
\hline Myristic acid (14:0) & $0.61^{\mathrm{a}} \pm 0.06$ & $0.55^{\mathrm{ab}} \pm 0.02$ & $0.52^{\mathrm{b}} \pm 0.03$ \\
Palmitic acid (16:0) & $25.72^{\mathrm{a}} \pm 1.15$ & $24.33^{\mathrm{a}} \pm 0.53$ & $24.59^{\mathrm{a}} \pm 0.63$ \\
Palmitoliec acid (16:1 n7) & $4.79^{\mathrm{a}} \pm 1.26$ & $4.61^{\mathrm{a}} \pm 0.28$ & $4.92^{\mathrm{a}} \pm 0.192$ \\
Stearic acid (18:0) & $6.35^{\mathrm{a}} \pm 1.03$ & $6.45^{\mathrm{a}} \pm 0.64$ & $6.28^{\mathrm{a}} \pm 0.36$ \\
Oleic acid (18:1 n9) & $37.01^{\mathrm{a}} \pm 3.10$ & $40.24^{\mathrm{a}} \pm 0.67$ & $40.24^{\mathrm{a}} \pm 1.96$ \\
Linoleic acid (18:2 n6) & $19.99^{\mathrm{a}} \pm 1.13$ & $19.93^{\mathrm{a}} \pm 1.03$ & $19.82^{\mathrm{a}} \pm 0.30$ \\
$\alpha$-Linoleic acid (18:3 n3) & $0.64^{\mathrm{a}} \pm 0.32$ & $0.79^{\mathrm{a}} \pm 0.32$ & $1.05^{\mathrm{a}} \pm 0.18$ \\
Gondoic acid (20:1 n9) & $0.49^{\mathrm{a}} \pm 0.07$ & $0.40^{\mathrm{a}} \pm 0.08$ & $0.40^{\mathrm{a}} \pm 0.07$ \\
11,14 Eicosadienoic acid (20:2 n6) & $0.50^{\mathrm{a}} \pm 0.20$ & $0.50^{\mathrm{a}} \pm 0.18$ & $0.30^{\mathrm{a}} \pm 0.09$ \\
Dihomo- $\gamma$-Linolenic acid (20:3 n6) & $0.59^{\mathrm{a}} \pm 0.20$ & $0.34^{\mathrm{a}} \pm 0.05$ & $0.50^{\mathrm{a}} \pm 0.10$ \\
Behenic acid (22:0) & $0.30^{\mathrm{a}} \pm 0.02$ & $0.24^{\mathrm{a}} \pm 0.05$ & $0.35^{\mathrm{a}} \pm 0.02$ \\
Arachidonic acid (20:4 n6) & $2.19^{\mathrm{a}} \pm 0.39$ & $1.35^{\mathrm{b}} \pm 0.04$ & $0.65^{\mathrm{b}} \pm 0.25$ \\
Adrenic acid (22:4 n6) & $0.76^{\mathrm{a}} \pm 0.29$ & $0.42^{\mathrm{a}} \pm 0.10$ & $0.40^{\mathrm{a}} \pm 0.18$ \\
& & & \\
SFA* & $32.38^{\mathrm{a}} \pm 2.55$ & $31.44^{\mathrm{a}} \pm 0.91$ & $31.48^{\mathrm{a}} \pm 0.45$ \\
MUFA** & $42.08^{\mathrm{a}} \pm 4.79$ & $45.26^{\mathrm{a}} \pm 0.92$ & $45.94^{\mathrm{a}} \pm 2.05$ \\
PUFA*** & $24.15^{\mathrm{a}} \pm 0.77$ & $22.79^{\mathrm{ab}} \pm 0.56$ & $21.77^{\mathrm{b}} \pm 0.72$ \\
PUFA/SFA & $0.74^{\mathrm{a}} \pm 0.01$ & $0.71^{\mathrm{ab}} \pm 0.01$ & $0.69^{\mathrm{b}} \pm 0.01$ \\
\hline
\end{tabular}

Means within lines with different superscript are significantly different $(\mathrm{p} \leq 0.05)$.

*SFA - Saturated fatty acid $=(\mathrm{C} 14: 0+\mathrm{C} 16: 0+\mathrm{C} 18: 0+\mathrm{C} 22: 0)$.

$* *$ MFA - Monounsaturated fatty acid $=(\mathrm{C} 17: 1+\mathrm{C} 18: 1+\mathrm{C} 20: 1)$.

***PFA - Polyunsaturated fatty acid $=(\mathrm{C} 18: 2+\mathrm{C} 18: 3+\mathrm{C} 20: 2+\mathrm{C} 20: 3+\mathrm{C} 20: 4+\mathrm{C} 22: 4$.

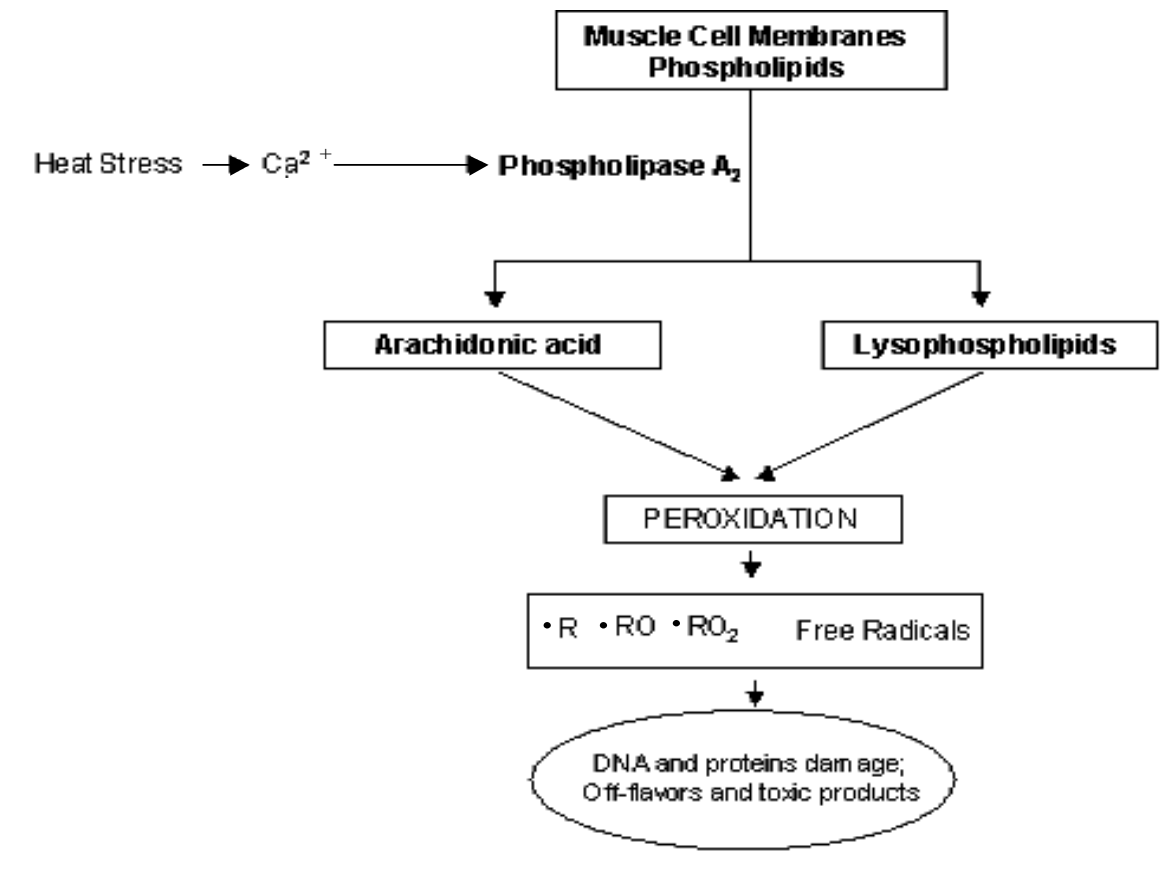

Figure 1 - Proposed scheme for arachidonic acid metabolism through phospholipase A2 action over muscle cell membranes. 
The ratio of PUFA/SFA was highest in PSE compared to normal and DFD-like meat of 0.736, 0.713 and 0.694 , respectively. These results were consistent with those reported by Duthie et al (1992) and Cheah and Cheah (1981), a higher percentage of this fatty acid being found in malignant hyperthermia-susceptible pigs muscle homogenates compared to resistant pigs. This enzyme acts upon phospholipid membranes liberating arachidonic acid and lysophospholipids (Murakami and Kudo, 2002) which may influence the sarcoplasmic reticulum $\mathrm{Ca}^{2+}$ release (Cheah and Cheah, 1981, Cheah et al., 1986). In fact, this area has been shown ultramicroscopically to be one of the most affected areas within the chicken PSE muscle sarcomere with a profound alteration during its hyper contraction (Guarnieri et al, 2004).

\section{CONCLUSIONS}

Broiler breast meat color abnormalities have their origin in several biochemical and physiological causes and the consequent lipid oxidation has a relevant role. The appearance of arachidonic acid in significant concentration in PSE meat reveals its potentially pivotal role in damaging cell membranes. Present results emphasize the importance of phospholipase A2 activity under elevation of $\mathrm{Ca}^{2+}$ as a triggering factor initiating intracellular degenerative processes within poultry skeletal muscle.

\section{ACKNOWLEDGMENTS}

This work was partially financed by $\mathrm{CNPq}$ (Process \# 471665/04-5), Fundação Araucária (Protocol \# 5230). ALS holds a CNPq postdoctoral position DFM and AAD were under $\mathrm{CNPq}$ and CAPES post-graduate scholarships, respectively. MM, EII and MS are CNPq Research Fellows.

\section{RESUMO}

A influência da oxidação lipídica no surgimento das anormalidades das cores do filé do peito de frango (Pectoralis major) foi avaliado. A oxidação lipídica foi $27 \%$ maior em carnes PSE em relação ao normal e $41,0 \%$ em relação ao análogo DFD $(\mathrm{p} \leq 0.05)$. O perfil dos ácidos graxos foi também significantemente diferente desde que a fração do ácido araquidônico (AA) aumentou 38,6\% e $70,5 \%$ em carnes PSE em comparação às carnes normais e análogas ao DFD, respectivamente. A razão PUFA/SFA se alterou nos três tipos de carne, 0,736, 0,713 e 0,694 para carnes PSE, normal e análogo ao DFD, respectivamente, refletindo a maior produção dos ácidos graxos polinsaturados em amostras PSE. Esses resultados corroboram os nossos anteriores, indicando que a atividade da enzima fosfolipase A2 tem um papel relevante no desenvolvimento da síndrome do PSE em uma cascata de reações bioquímicas promovendo a formação dos compostos radicais livres do AA que finalmente compromete os sistemas das membranas celulares do músculo.

\section{REFERENCES}

Cheah, K. S. and Cheah, A. M. (1981), Skeletal muscle mitochondrial phospholipase $\mathrm{A} 2$ and the interaction of mitochondrial and sarcoplasmic reticulum in porcine malignant hyperthermia. Biochem. Biophys. Acta, 648, 113.

Cheah, K. S., Cheah, A. M. and Waring J. C. (1986), Phospholipase A2 activity, calmodulin, $\mathrm{Ca}^{2+}$ and meat quality in young and adult halothane-sensitive and halothane-insensitive British Landrace pigs. Meat Sci., 17, 37-53.

Duthie, G. G., Wahle, K., Harris, C. I. and Arthur, J. R. (1992), Lipid peroxidation, antioxidant concentrations and fatty acid contents of muscle tissue from malignant hyperthermia-susceptible swine. Arch. Biochem.Biophys., 296, 592-296.

Guarnieri, P. D., Soares, A. L., Olivo, R., Schneider, J. P., Macedo, R. M., Ida, E. I. and Shimokomaki, M. (2004), Preslaughter handling with water shower spray inhibits PSE (Pale, Soft, Exudative) broiler breast meat in a commercial plant. Biochemical and Ultrastructural observations. J. Food Biochemistry, 28, 269-277.

ISO - International Organization for Standardization. (1978). Animal and vegetable fats and oils preparation of methyl esters of fatty acids. Method ISSO 5509.

Lara, J. A. F., Nepomuceno, A. L., Ledur, M. C, Ida, E. I. and Shimokomaki, M. (2003), Mutations in the ryanodine receptor gene. Proc. Int. Congr. Meat Sci. Technol., 49, 79-80.

Morrisey, P. A., Sheehy, P. J. A., Galvin, K., Kerry, J. P. And Buckley, D. L. (1998), Lipid stability in meat and meat products. Meat Sci., 49, 73 - 86s. 
Murakami, M. and Kudo, I. (2002). Phospholipase A2. J. Biochemistry (Tokyo), 131, 285-292.

Northcutt, J. K. (2001), Preslaughter factors affecting poultry meat quality. In Poultry Meat Processing (A. R. Sams, ed.) CRC Press. Boca Raton, pp 5-18,.

Olivo, R., Soares, A. L., Ida, E. I. and Shimokomaki, M. (2001), Dietary vitamin E inhibits poultry PSE and improves meat functional properties. J. Food Biochemistry, 25, 271-283.

Ruiz, M. R., Matsushita, M., Visentainer, J. V., Hernandez, J. A., Ribeiro, E. L. De A., Shimokomaki, M., Reeves, J.J. and Souza, N.E (2005), Proximate chemical composition and fatty acid profiles of Longissimus dorsi from pasture fed LHRH immunocastrated, castrated and intact Bos indicus bulls. South African J. Animal Sci., 35, 13-18.

Soares, A. L., Lara, J. A. F. Ida, E. I., Guarnieri, P. D., Olivo, R. and Shimokomaki, M. (2002). Variation in the Color of Brazilian Broiler Breast Fillet. Proc. Internat. Congr. Meat Sci. Technol., 48, 540-541.

Soares, A. L., Lara, J. A. F.; Ida, E. I., Guarnieri, P. D., Olivo, R, and Shimokomaki, M. (2003a), Influence of preslaughter handling practices on broiler meat color in a commercial plant. Proc. IFT Annual Meeting, (p.201), Chicago.
Soares, A., L., Ida, E. I., Miyamoto, S., Blazquez, F. J. H., Olivo, R., Pinheiro, J.W. And Shimokomaki, M. (2003b), Phospholipase A2 Activity in Poultry PSE, Pale, Soft, Exudative, J. Food Biochemistry, 27, 309319.

Soares, A. L., Olivo, R., Shimokomaki, M. and Ida, E. I. (2004), Synergism between dietary vitamin E and exogenous phytic acid in prevention of warmed-over flavour development in chicken breast meat, Pectoralis major M. Brazilian Archives of Biology and Technology, 47, 57-62.

St Angelo, A. J. (1996), Lipid oxidation in foods. Crit. Rev. Food Sci. Nutr., 36, 175-224.

Strasburg, G. M. and Chiang, W. (2003). Genetic Basis for Pale, Soft and Exudative Turkey meat. Reciprocal Meat Conference, 56, 17- 22.

Tarladgis, B. G., A. M. Pearson and L. R. Jr. Dugan, (1964), Chemistry of the 2-thiobarbituric test for determination of oxidative rancidity in foods II. Formation of the TBA-malonaldehyde complex without acid-heat treatment. J. Food Sci. Agric., 5, 602-604.

Received: August 22, 2007; Revised: March 14, 2008; Accepted: July 13, 2009. 